\title{
Kinetic Model of Thermophilic Biohydrogen Production from POME
}

\author{
Mohd Hafis Irsyad Mohd Faudzi ${ }^{1}$, Jamaliah Md Jahim ${ }^{1,2^{*}}$, Peer Mohamed \\ Abdul ${ }^{1,2}$, Chen-Yeon $\mathrm{Chu}^{3,4}$, Shu-Yii $\mathrm{Wu}^{5}$, Mohd Sobri Takriff ${ }^{1,2}$, Shuhaida \\ Harun $^{1,2}$
}

${ }^{1}$ Research Centre for Sustainable Process Technology (CESPRO), Faculty of Engineering and Built Environment, Universiti Kebangsaan Malaysia, 43600 UKM Bangi, Selangor, MALAYSIA

${ }^{2}$ Chemical Engineering Programme, Faculty of Engineering and Built Environment, Universiti Kebangsaan Malaysia, 43600 Bangi, Selangor, MALAYSIA

\author{
${ }^{3}$ Master's Program of Green Energy Science and Technology, Feng Chia University, Taichung 40724, TAIWAN \\ ${ }^{4}$ Institute of Green Products, Feng Chia University, Taichung 40724, TAIWAN
}

${ }^{5}$ Department of Chemical Engineering, Feng Chia University, Taichung 40724, TAIWAN

DOI: https://doi.org/10.30880/ijie.2019.11.07.028

Received 16 July 2019; Accepted 20 October 2019; Available online 15 November 2019

\begin{abstract}
The study of fermentation kinetic parameters are crucial to understand the environmental factors affect on biohydrogen production. Kinetic models for hydrogen production from anaerobic digestion of palm oil mill effluent (POME) by mixed culture were developed based on published work. The models accounted for substrate limitation, substrate inhibition, hydrogen production, and endogenous decay rate. Data from previous literature were used to compare four microbial growth kinetic models for hydrogen production in an ASBR system. The estimated values of the maximum specific growth rate $\left(\mu_{\mathrm{m}}\right)$ were found to be $0.371 \mathrm{~h}^{-1}$. In this study, the parameters of $\mathrm{Y}, \mathrm{k}_{\mathrm{d}}$, and $\mathrm{B}_{0}$ calculated were $2.64 \mathrm{gVSS} / \mathrm{gCOD}, 0.053 \mathrm{~h}^{-1}$, and $0.133 \mathrm{~L} \mathrm{H}_{2} / \mathrm{gCOD}$, respectively. The model fitting was found to be in good agreement with the experimental and can be utilized for the optimization and design of the process.
\end{abstract}

Keywords: Kinetic models; Biohydrogen; POME;

\section{Introduction}

Hydrogen is considered as the primary energy carrier of the future with a high-energy content of $122 \mathrm{~kJ} \mathrm{~g}^{-1}$, which is 2.75 times greater than hydrocarbon fuels [1]. In Malaysia, the Ministry of Science, Technology, and Innovation (MOSTI) have selected to prioritize research on the hydrogen fuel cell. Between 2002 and 2007, MOSTI had funded US\$2 million on hydrogen production and storage technologies, and US\$9.7 million from 1995 to 2007 on the national fuel cell research and development [2,3]. Dark fermentation has high efficiency of biohydrogen production. The process is environmentally friendly and feasible to commercialize [4]. Compare to photo fermentation, dark fermentation has lower operating costs since it does not require the input of light energy. In addition, dark fermentation is competent with a wide variety of substrates. Since dark fermentation lack oxygen evolution, it has a much stable hydrogen-producing enzyme [5]. Palm oil mill effluent (POME) is a possible substrate to be used for dark fermentation due to the high compositions and concentrations of carbohydrates, proteins, nitrogenous compounds, lipids, and minerals [6, 7]. Until 
2011, 55 out of 426 palm oil mills in Malaysia had installed biogas plants [8] and 43.29 million cubic meters per year of POME were generated during milling process based on calculation from $2.5 \mathrm{~m}^{3}$ raw POME generated [9].

The study of fermentation kinetic parameters is crucial to understand the effect of the environmental factors on biohydrogen production. The fermentation process of palm oil mill effluent involves the conversion of organic compounds to liquid organics and biogas, which is relatively complex. Furthermore, kinetic parameters, coupled with the mathematical model, can be used to predict the substrate utilization, cell concentration, and biohydrogen production rate during steady-state. This paper aimed to present a kinetic model for the thermophilic POME fermentation in an anaerobic sequential batch reactor (ASBR) by a mixed culture. The model can be used for understanding the behavior of the anaerobic digestion under most related environmental conditions for biohydrogen production. The weighted least-squares parameter estimation method was used to compute the kinetic model parameters from the previous literature data. Mathematical models base on Monod's equation accounting for substrate inhibition were developed to predict hydrogen fermentation.

\begin{tabular}{|c|c|}
\hline \multicolumn{2}{|c|}{ Nomenclature } \\
\hline B & $\begin{array}{l}\text { volume of hydrogen produced under STP per } \\
\text { gram of substrate loaded }\left(\mathrm{L} \mathrm{H}_{2, \mathrm{STP}} / \mathrm{g}\right.\end{array}$ \\
\hline $\mathrm{B}_{0}$ & $\begin{array}{l}\text { volume of hydrogen produced under STP per } \\
\text { gram of substrate loaded at infinite retention }\end{array}$ \\
\hline $\mathrm{dS} / \mathrm{dt}$ & $\begin{array}{l}\text { time }\left(\mathrm{L} \mathrm{H}_{2, \mathrm{sTP}} / \mathrm{g} \mathrm{COD}_{\text {loaded }}\right) \\
\text { substrate utilization rate }(\mathrm{g} / \mathrm{L} . \mathrm{h})\end{array}$ \\
\hline $\mathrm{dX} / \mathrm{dt}$ & Microbial growth rate (g/L.h) \\
\hline $\mathrm{D}$ & dilution rate $\left(\mathrm{h}^{-1}\right)$ \\
\hline $\mathrm{H}$ & $\begin{array}{l}\text { volumetric hydrogen production rate ( } \mathrm{L} \\
\mathrm{H}_{2} / \mathrm{L} / \mathrm{h} \text { ) }\end{array}$ \\
\hline K & $\begin{array}{l}\text { Chen \& Hashimoto model dimensionless } \\
\text { kinetic parameter }\end{array}$ \\
\hline $\mathrm{k}^{\prime}$ & First-order rate constant $\left(\mathrm{d}^{-1}\right)$ \\
\hline $\mathrm{k}_{\mathrm{d}}$ & endogenous decay constant $\left(\mathrm{h}^{-1}\right)$ \\
\hline $\mathrm{K}_{\mathrm{S}}$ & $\begin{array}{l}\text { Monod model half-saturation constant } \\
(\mathrm{gCOD} / \mathrm{L})\end{array}$ \\
\hline M & cumulative hydrogen production $(\mathrm{mL})$ \\
\hline $\mathrm{n}$ & number of samples \\
\hline $\mathrm{P}$ & hydrogen production potential $(\mathrm{mL})$ \\
\hline Q & flow rate $(\mathrm{L} / \mathrm{d})$ \\
\hline $\mathrm{R}$ & maximum hydrogen production rate $(\mathrm{mL} / \mathrm{h})$ \\
\hline $\mathrm{R}^{2}$ & coefficient of determination \\
\hline $\mathrm{S}$ & effluent substrate concentration $(\mathrm{g} / \mathrm{L})$ \\
\hline $\mathrm{S}_{0}$ & influent substrate concentration $(\mathrm{g} / \mathrm{L})$ \\
\hline $\mathrm{V}$ & digester working volume (L) \\
\hline $\mathrm{X}$ & effluent biomass concentration $(\mathrm{g} / \mathrm{L})$ \\
\hline $\mathrm{X}_{0}$ & influent biomass concentration $(\mathrm{g} / \mathrm{L})$ \\
\hline Y & growth yield coefficient \\
\hline$\theta$ & hydraulic retention time $(\mathrm{h})$ \\
\hline$\lambda$ & lag-phase time (h) \\
\hline$\mu$ & specific microbial growth rate $\left(\mathrm{h}^{-1}\right)$ \\
\hline$\mu_{\mathrm{m}}$ & maximum specific microbial growth rate $\left(\mathrm{h}^{-1}\right)$ \\
\hline$\hat{i}$ & $\begin{array}{l}\text { actual value } \\
\text { predicted value }\end{array}$ \\
\hline- & average of actual value \\
\hline
\end{tabular}




\section{Process Description}

In general, the anaerobic digestion (AD) process is a series of complex reactions that broadly involve 2 groups of anaerobic or facultative anaerobic microorganisms: acidogens and methanogens. Acidogen focuses on removing the pollutant by breaking down the organic compounds to volatile fatty acids and $\mathrm{CO}_{2}$ while the methanogen focuses on converting the acidogens' products to methane [10]. Both processes can either be run sequentially or simultaneously. However, the optimum $\mathrm{pH}$ level for acidogen and methanogen is different. Thus, by conducting sequentially and separately, the optimum operating of the AD process can be achieved [11]. The conventional reactors used for anaerobic digestion of wastewater are a single-stage process or a two-stage process. In the single-stage process, all reactions occur simultaneously in a single reactor which includes hydrolysis, acidification, and methanogenesis. This system allows simpler designs that have a smaller investment cost and low maintenance cost due to less frequent technical failures [12, 13]. On the other hand, in the two-stage process, hydrolysis and acidogenesis will first react in the first reactor. Then, in the second reactor, the produced acids from the first reactor are utilized by the methanogenesis.

POME is known for its complex form causing difficulties for its degradation to short-chain derivatives [14]. In comparison, a lower reactor volume and higher theoretical yield could be achieved using the two-stage process compared to the single-stage process. Moreover, at lower hydraulic retention time (HRT) and higher organic loading rate (OLR), the two-stage system is found to be more stable while the single-phase process could not handle the further decrease in the HRT and increase in the ORL $[15,16]$. HRT, OLR and POME characteristics were found to significantly affect the AD process [17]. Through energy recovering analysis, the two-stage process showed significant enhancement to the single-stage by a 3.3-fold increase by comparing both processes' highest energy recoveries. The two-phase process could also achieve higher hydrogen and methane yield compared to the single-phase process [18]. Negligible differences in the cost of production were calculated when single $\mathrm{CH}_{4}$ and hythane (mixture of $\mathrm{H}_{2}+\mathrm{CH}_{4}$ ) production were compared. However, in terms of the overall production of energy, an increase of $12-25 \%$ was observed for the two-stage system [19].

\section{Review of POME Anaerobic Digestion Kinetics}

\subsection{Kinetics of Cell Growth and Substrate Utilization}

Kinetic models are useful tools for analyzing, designing, and optimizing the fermentation process for hydrogen production [20]. To date, not much research had been done on the kinetic study of POME anaerobic digestion for hydrogen production. Mohammadi et al. [21] conducted a kinetic evaluation of biological hydrogen production using POME as the substrate in a modified up-flow anaerobic sludge blanket fixed film (UASB-FF) reactor. They found that the Monod model that follows the Line Weavear-Burk equation was suitable for computation and analysis of the kinetic parameters of substrate inhibition and cell carrying capacity in their reactor system.

Banik et al. [22] found that ASBR kinetics at $5^{\circ} \mathrm{C}$ did not follow the Monod model as well where the value of $\mathrm{K}(\mathrm{T})$ and $\mu_{\mathrm{m}}$ were also negative. Similarly, Ma et al. [23] found that the Monod equation gives a weak correlation with experimental data due to the limitation of the Monod model being independent of the influent substrate concentration $\left(\mathrm{S}_{0}\right)$. They also noted that the digester performance is affected by organic loading. Dinopoulou et al. [24] also found that the Monod equation failed to represent the acidogenic bacteria growth in their continuous stirred tank reactor (CSTR) system. In this study, First-order, Monod, Grau, and Chen \& Hashimoto model study for kinetic evaluation. Monod study was still considered in this study for comparison with the other three models.

\subsection{Kinetics of Product Formation}

The most common kinetic model for product formation is the modified Gompertz equation. This model can be used to model the cumulative hydrogen production $(\mathrm{M})$, hydrogen production potential $(\mathrm{P})$, hydrogen production rate $(\mathrm{R})$, and lag phase $(\lambda)$ for a cumulative biogas production time $(\mathrm{t})$ as follow:

$$
M=\cdot\left\{-\left[\frac{\cdot}{H}(-)+1\right]\right\}
$$

The assessment of hydrogen production performance was based on the hydrogen yield as well as the volumetric hydrogen production rate (VHPR) as the major performance indexes. The yield was defined as mol of hydrogen produced per mol of substrate utilized. The kinetic constant computed from the modified Gompertz equation (Eq. (1)) determined the volumetric hydrogen production rate.

By minimizing the sum square of errors (SSE), the modified Gompertz equation with help from various choices of statistical software can be used to estimate these parameters between experimental data and estimation from the models. Studies show that the modified Gompertz equation could well match the fermentative hydrogen production from POME with a regression coefficient higher than 0.9 . Research on the inhibitions effect on hydrogen production from POME by $\mathrm{AD}$ has been presented by several researchers. Table 1 shows the summary of estimated parameters using the Gompertz equation for hydrogen production from the $\mathrm{AD}$ of POME. 
Table 1: Estimated parameters of the Gompertz equation for hydrogen production from POME anaerobic digestion

\begin{tabular}{|c|c|c|c|c|c|c|}
\hline \multicolumn{2}{|l|}{ Parameter } & $\begin{array}{r}\mathbf{P} \\
(\mathbf{m}\end{array}$ & $\begin{array}{c}\mathbf{R} \\
(\mathrm{mL} / \mathrm{L} /\end{array}$ & ${ }^{\lambda}$ & $\begin{array}{r}\text { Working volume / } \\
\text { Total volume }\end{array}$ & Reference \\
\hline \multirow{5}{*}{$\mathrm{pH}$} & 5 & 123 & 9 & 1 & $25 \mathrm{~mL} / 50 \mathrm{~mL}$ & \multirow{8}{*}[25]{} \\
\hline & 5.5 & 216 & 2 & 1 & $25 \mathrm{~mL} / 50 \mathrm{~mL}$ & \\
\hline & 6 & $\begin{array}{l}197 \\
n\end{array}$ & 2 & 1 & $25 \mathrm{~mL} / 50 \mathrm{~mL}$ & \\
\hline & 6.5 & $\begin{array}{l}208 \\
1\end{array}$ & $\begin{array}{l}2 \\
6\end{array}$ & 2 & $25 \mathrm{~mL} / 50 \mathrm{~mL}$ & \\
\hline & 13 & $\begin{array}{l}158 \\
2\end{array}$ & $\begin{array}{l}5 \\
2\end{array}$ & 4 & $25 \mathrm{~mL} / 50 \mathrm{~mL}$ & \\
\hline \multirow{3}{*}{$\begin{array}{l}\text { Sucrose concentration } \\
(\mathrm{mM})\end{array}$} & 23 & $\begin{array}{l}170 \\
\text { E }\end{array}$ & $\begin{array}{l}1 \\
0\end{array}$ & 17 & $25 \mathrm{~mL} / 50 \mathrm{~mL}$ & \\
\hline & 33 & $\begin{array}{l}186 \\
\mathrm{e}\end{array}$ & $\begin{array}{l}1 \\
2\end{array}$ & 17 & $25 \mathrm{~mL} / 50 \mathrm{~mL}$ & \\
\hline & 43 & 219 & 1 & 20 & $25 \mathrm{~mL} / 50 \mathrm{~mL}$ & \\
\hline \multirow[b]{2}{*}{$\mathrm{pH}$ controller } & Initial $\mathrm{pH}$ & 962 & $\begin{array}{l}1 \\
1\end{array}$ & 6 & $\begin{array}{l}1 \mathrm{~L} / \\
2 \mathrm{~L}\end{array}$ & \multirow[b]{2}{*}[26]{} \\
\hline & $\begin{array}{c}\text { Controlled } \\
\mathrm{pH}\end{array}$ & $\begin{array}{l}132 \\
1\end{array}$ & $\begin{array}{l}1 \\
4\end{array}$ & 7 & $\begin{array}{l}1 \mathrm{~L} / \\
2 \mathrm{~L}\end{array}$ & \\
\hline
\end{tabular}

However, the modified Gompertz equation is more suitable for modeling a batch system where the performance of the system is based on cumulative hydrogen production per operation time that follows the sigmoidal shape. For a semibatch system such as ASBR, the performance of the system is based on the hydrogen production rate at a steady-state per different dilution rate. Therefore mathematical modeling based on mass balance is more suitable for modeling product formation in a continuous system.

\section{Kinetic Model Parameters}

Two different approaches are usually used to study the fermentation of complex substrate fermentation. These substrates include municipal, industrial, and residues from animals. The first approach is to evaluate the kinetic parameters by finding the rate-limiting substrate. The second approach is to represent the substrate concentration through the concentration of volatile solids (VS) and chemical oxygen demand (COD). Even though the latter approach is convenient in evaluating the overall process performance, it is challenging to use VS or COD as a gross substrate. In addition, not all portion of VS or COD is available to the substrate and microbes [27]. In this study, total carbohydrate (TC) in the reactor is used as the rate-limiting substrate. For a steady-state behavior system, the kinetic model based on material balance was developed for the process component of the hydrogen-producing bioreactor. These estimated kinetic parameters are essential in predicting the industrial-scale bioreactor performance. These parameters include cell yield coefficient $(\mathrm{Y})$, endogenous decay coefficient $\left(\mathrm{k}_{\mathrm{d}}\right)$, maximum specific growth rate $\left(\mu_{\mathrm{m}}\right)$ and half velocity constant $\left(\mathrm{K}_{\mathrm{S}}\right)$

\subsection{Yield Coefficient, Y, and Endogenous Decay Coefficient, $k_{d}$}

The micro-organisms will metabolize their own protoplasm (autodigestion) when the substrate concentration in the wastewater is at its minimum. Furthermore, the death of some cells causes a decrease in biomass concentration in the reactor. This phenomenon can be described by a coefficient known as endogenous decay, $\mathrm{k}_{\mathrm{d}}$. The endogenous decay coefficient accounts for the loss in cell mass. The causes of losses are due to predation by higher food chain organisms, death of cells, and energy requirement for cell maintenance through oxidation of internal storage products. The net amount of sludge to be handled can be estimated by utilizing the endogenous decay coefficient [28] while the total amount of sludge produced through wastewater treatment can be estimated by the cell yield coefficient [29].

\subsection{Maximum Specific Growth Rate, $\mu_{\mathrm{m}}$, and Half Velocity Constant, $\mathrm{Ks}_{\mathrm{s}}$}

Maximum specific growth rate, $\mu_{\mathrm{m}}$ is used for determining the volume of biological reactors. The size of the reactor is getting smaller, as $\mu_{\mathrm{m}}$ becomes greater [28]. $\mathrm{K}_{\mathrm{S}}$, on the other hand, has no direct application in designing the process. It only gives an idea of the relationship between the concentrations of the growth-limiting substrate to the growth rate of bacteria. [29]. Fdez-Güelfo et al. found that the value of $K_{S}$ may be associated with the ability of microorganisms to degrade the substrate present in the waste to produce hydrogen. [30]. 


\subsection{The Volume of Hydrogen Produced Under Standard Condition Per Gram of Substrate Loaded at Infinite Retention Time ( $\mathrm{L} \mathrm{H}_{2}$, sTp/gCOD $\left.{ }_{\text {loaded }}\right)$, $\mathrm{B}_{0}$}

$\mathrm{B}_{0}$ is defined as the final attainable hydrogen production per $\mathrm{g}$ of the total carbohydrate of the given substrate. The value of $\mathrm{B}_{0}$ varies with temperature and type of substrate and manure. It was found that the value of $\mathrm{B}_{0}$ depends on the age of the manure, species, collection and storage, ration, and bedding material [23, 27].

\section{Materials and Methods}

\subsection{Acquisition of Data}

Data for kinetic analysis of POME anaerobic digestion in ASBR were acquired form the work of Maarof et al. [31]. Maarof et al. studied the effect of HRT and its relationship with the sugar consumption and solid retention time in a thermophilic temperature $\left(55^{\circ} \mathrm{C}\right)$ using a mixed culture at $\mathrm{pH} 5.5$ in an anaerobic sequential batch reactor (ASBR). Prediction of hydrogen production using the kinetic model was derived using data from digester operating at steady-state duration. Table 2 shows a summary of the work done by Maarof et al. [31]. Maarof et al. found that HRT 12 hours give the highest hydrogen yield while decreasing the HRT further to 6 hours reduce the hydrogen yield due to the washout of biomass.

\subsection{Development of Kinetic Model [23]}

Monod, First order, Grau, and Chen \& Hashimoto model were studied to choose the suitable model to fit the microbial growth kinetics of POME AD, as shown in Table 3. The relation between the concentrations of substrate (S) and specific microbial growth rate $(\mu)$ is a valuable tool in biotechnology.

Table 2: Summary of work done by Maarof et al. [31]

\begin{tabular}{lccccc}
\hline & \multicolumn{5}{c}{ HRT (h) } \\
\cline { 2 - 6 } Characteristics & $\mathbf{4}$ & $\mathbf{2}$ & $\mathbf{1}$ & $\mathbf{1}$ & $\mathbf{6}$ \\
\hline Hydrogen Yield (mol & 0. & 1.02 & 2. & 2.99 & 2.62 \\
$\mathrm{H}_{2}$ mol $_{\text {sugar }}$ ) Soluble metabolic & 38 & & 01 & & \\
Acetic acid & 5. & 4.82 & 4. & 2.80 & 4.31 \\
Butyric acid & 10 & 8.15 & 13.80 & 14.81 & 0.68 \\
Propionic acid & 0. & 0.79 & 0. & 0.87 & 0.70 \\
Ethanol & $3 . \hat{9}$ & 4.08 & $4 . \overline{4}$ & 4.73 & 3.21 \\
\hline
\end{tabular}

Table 3: Kinetic models used in this study

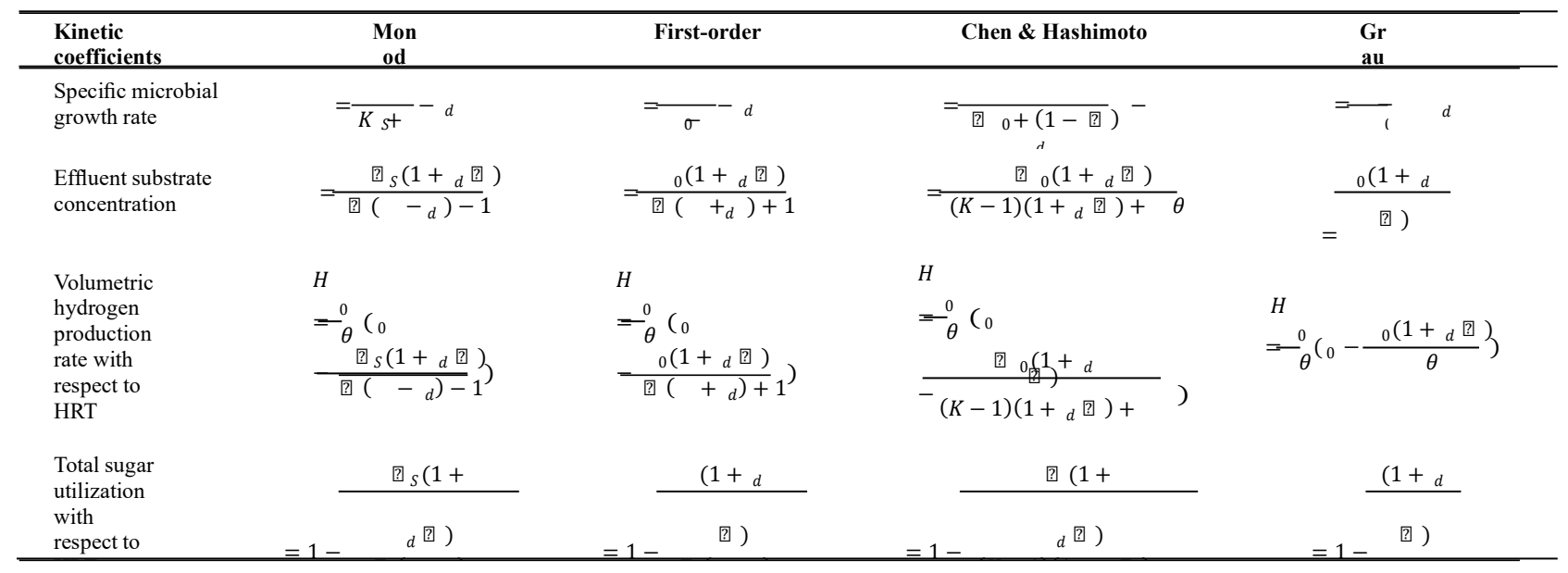

\subsection{First-order Model}

The first-order kinetic model [32] states that the rate of a substrate with varied substrate concentration in a reactor with respect to time can be expressed by using a mass balance equation as follows: 


$$
-(-)=\left(\frac{-}{V}\right)-\left(\frac{-}{V}\right)_{0}-
$$

Under the steady-state condition, the rate of substrate concentration is negligible, which reduces Eq. (2) to:

$$
=\overline{0}_{0}^{-} d
$$

Generally, it is believed that the batch culture growth rate during the exponential phase follows the first-order kinetic model, where the growth rate is proportional to the number of microbes in the system.

\subsection{Monod Model}

Monod model [33] is proposed by the theory that substrate concentration around microorganisms is also significantly considered in the evaluation of the kinetic parameter. Monod's model defines two parameters, the maximum specific growth rate $\left(\mu_{\mathrm{m}}\right)$, and the substrate affinity constant $\left(\mathrm{K}_{\mathrm{s}}\right)$ to relate the microbial growth rate to the concentration of a single growth-limiting substrate as follows:

$$
\mu=\frac{\mu_{m} S}{K_{S}+S}-k_{d}
$$

\subsection{Chen and Hashimoto Model}

Chen et al. [27] developed a kinetic model on substrate utilization based on the Contois model. The kinetic model has been mostly applied in many research, particularly in studies on $\mathrm{AD}$ of high strength wastes [34, 35]. Chen and Hashimoto's models suggested that the predicted permeate COD concentration (S) is a function of influence COD concentration $\left(\mathrm{S}_{0}\right)$. However, in the Monod model, the permeate COD concentration, $\mathrm{S}$ is independent of $\mathrm{S}_{0}$.

$$
=\frac{}{?_{0}+(1-?)}-d
$$

\subsection{Grau Model}

Grau et al. [36] developed a model to determine the removal of a multicomponent substrate by activated sludge. This model was expanded in the basic concept of linear removal of the special case of the Monod model. In this model, the reaction order was analogous to the order of chemical reaction with a constant rate that is not limited to integers [36].

$$
=\frac{-}{0}-d
$$

\subsection{Microbial Growth Mass Balance}

The microbial growth mass balance can be given as follows:

$$
V={ }_{0}-+() V
$$

At steady state, the term $\mathrm{dX} / \mathrm{dt}=0$. Thus, eq. (7) become:

$$
=\bar{V}=\frac{1}{\theta}
$$

The maximum growth rate indicates the minimum retention time when the microbial washout occurs.

\subsection{Determination of Yield Coefficient, $Y$, and Endogenous Decay Coefficient, $k_{d}$}

From a mass balance of cell concentration (X) and substrate concentration (S) at steady state, $\mathrm{Y}$ and $\mathrm{k}_{\mathrm{d}}$ can be found by using the following equation [37]: 


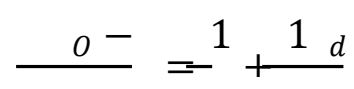

By plotting a graph of $1 / \mathrm{D}$ and $\left(\mathrm{S}_{0}-\mathrm{S}\right) / \mathrm{X}$ along the $\mathrm{x}$-axis and $\mathrm{y}$-axis respectively, the intercept of the $\mathrm{y}$-axis was used to find the yield coefficient, while the slope of the line was used to find $\mathrm{k}_{\mathrm{d}}$.

\subsection{Estimation of Volumetric Hydrogen Production Rate}

The rate-limiting substrate approach was used for the kinetic evaluation study of hydrogen fermentation of complex substrate. If B denotes the volume of hydrogen produced at STP per gram of substrate loaded to the digester, and $\mathrm{B}_{0}$ is the volume of hydrogen produced at STP per gram of substrate loaded at infinite retention time, then the biodegradable substrate in the digester will be directly proportional to $\mathrm{B}_{0}-\mathrm{B}$, and $\mathrm{B}_{0}$ will be directly proportional to the biodegradable substrate loading. This method was applied from the work of Chen and Hashimoto [27] for the prediction of methane production rate. Thus, the relationship can be derived as follows:

$$
-\quad=\frac{0-}{0}
$$

Eq. (10) can be rearranged to give:

$$
={ }_{0}\left(\frac{n-}{0}\right)
$$

The volumetric hydrogen production rate is the product of B and OLR, which gives:

$$
H=\frac{0}{\theta}
$$

Combining Eq. (11) with Eq. (12), the volumetric hydrogen production rate can be expressed as:

$$
H=\frac{0}{\theta}(0-)
$$

\subsubsection{Determination of Volume of Hydrogen Produced under Standard Condition per Gram of Substrate Loaded at Infinite Retention Time ( $\mathrm{L} \mathrm{H}_{2}, \mathrm{STP} / \mathrm{g}$ COD Loaded), Bo}

The value of $\mathrm{B}_{0}$ can be derived from the mass balance of substrate consumption as:

$$
V \frac{\mathrm{dS}}{\mathrm{dt}}={ }_{0}-+(-) V^{\prime}
$$

At steady state, $\mathrm{dS} / \mathrm{dt}=0$. Thus, the above equation can be simplified as:

$$
=\frac{0}{2^{\prime}+1}
$$

Substituting Eq. (15) into Eq. (13) and rearranging yields:

$$
\frac{0}{H}=\frac{\theta}{0}+\frac{1}{0}
$$

By plotting a graph of HRT versus $\mathrm{S}_{0} / \mathrm{H}$, the value of $\mathrm{B}_{0}$ for $\mathrm{AD}$ of POME used in this study was determined.

\subsection{Assessment of models performance}

The coefficient of determination or R-squared $\left(\mathrm{R}^{2}\right)$ is the common method in assessing the accuracy of a model. The $\mathrm{R}^{2}$ method measures the relationship between two variables as follow: 


$$
\begin{aligned}
& 2=1-\frac{\text { 目 }}{a \quad()}= \\
& =\sum\left({ }_{i} \hat{-}_{\text {回 }}\right)^{2} \\
& =\sum\left({ }_{i}-^{-}\right)^{2} \\
& =\sum\left({ }_{i}-^{-}\right)^{2}
\end{aligned}
$$

Where $\hat{i, \hat{i}}$ and are actual value, predicted value, and the average of actual value respectively. However, the $\mathrm{R}^{2}$ method assumes a linear relationship between the variables, thus, it can be inaccurate when fitting the model in this study. Root mean squared error (RMSE), relative squared error (RSE), mean absolute error (MAE), and relative absolute error (RAE) are used as the indicator in assessing the models.

$$
\begin{aligned}
& M=\sqrt{ } \frac{\overline{i=\sum\left({ }_{i}-{ }_{i}\right)^{2}}}{} \\
& =\frac{\sum_{0}}{\sum^{=1}} \\
& =1 \\
& M=\underline{\Gamma=1} \\
& \sum\left|{ }_{i}{ }^{\wedge}{ }_{i}\right| \\
& =0 \\
& =1 \\
& \sum\left|{ }_{i}{ }^{-}{ }_{i}\right|
\end{aligned}
$$$$
\left(i-\hat{}^{0}\right)^{2}
$$$$
\left(i-{ }^{-}\right)^{2}
$$$$
\left|{ }_{i}-{ }_{i}\right|
$$

\section{Result and Discussion}$$
=1
$$

\subsection{Kinetic Model Evaluation}

The aforementioned models; Monod, First-order, Chen and Hashimoto and Grau models were used to determine the most suitable model for the hydrogen production kinetic from POME in an ASBR digester. Table 4 shows the kinetic parameters value while Table 5 shows the fitting accuracy of each model. In terms of fitting the kinetic data set, it is found that the Grau model gives the lowest SSE, RMSE, RSE, MAE, and RAE compared to other models. Thus, the Grau model's ability to simulate the hydrogen production rate was further evaluated. Even though the Monod equation is the most common kinetic model used, it was found that the kinetic model of POME anaerobic digestion at thermophilic $\left(55^{\circ} \mathrm{C}\right)$ conditions in ASBR did not give a realistic value of $\mathrm{K}_{\mathrm{S}}$ and $\mu_{\mathrm{m}}$ (negative value). By definition of Monod kinetic parameters, Ks should be half-saturation of the Monod model while $\mu_{\mathrm{m}}$ is the maximum dilution rate of the process. The Monod model was considered in this study for comparison.

Table 4: Kinetic parameters value

\begin{tabular}{ll} 
Model & Kinetic parameters \\
\hline First-order & $\mu \mathrm{m}=0.434 \mathrm{~h}^{-1}$
\end{tabular}


Monod

$\mathrm{C} \& \mathrm{H}$

Grau
Irsyad et al., Int. J. of Integrated Engineering Vol. 11 No. 7 (2019) p. 219-232

$\mu \mathrm{m}=-0.434 \mathrm{~h}^{-1}$

$\mathrm{Ks}=-31.916 \mathrm{gCOD}^{-}$

$\mu \mathrm{m}=0.873 \mathrm{~h}^{-1}$

$\mathrm{K}=3.010$

$\mu \mathrm{m}=0.371 \mathrm{~h}^{-1}$ 
Table 5: Kinetic parameters and fitting accuracy comparison.

\begin{tabular}{cllllll}
\hline Model & SS & RMSE & RS & MAE & RAE \\
\hline First-order & 0.0120 & 0.0491 & 0.7025 & 0.0385 & 5.509 \\
Monod & 0.0073 & 0.0382 & 0.4260 & 0.0324 & 4.089 \\
C\&H & 0.0115 & 0.0479 & 0.6689 & 0.0374 & 5.373 \\
Grau & $\underline{0.0055}$ & $\underline{0.0333}$ & $\underline{0.3225}$ & $\underline{0.0298}$ & $\underline{3.8212}$
\end{tabular}

The biomass yield, $\mathrm{Y}$ and endogenous decay coefficient, $\mathrm{k}_{\mathrm{d}}$ were determined by using Eq. (9) as shown in Figure 1. According to Figure 1, intercept-y equal to $1 / \mathrm{Y}$ and slope equal to $\mathrm{k}_{\mathrm{d}} / \mathrm{Y}$. The kinetic parameters $\mathrm{Y}$ and $\mathrm{k}_{\mathrm{d}}$ from this study were determined as $2.64 \mathrm{gVSS} / \mathrm{gCOD}$ and $0.0531 \mathrm{~h}^{-1}$, respectively. $\mathrm{B}_{0}$ of POME was determined by plotting the value of HRT versus $\mathrm{S}_{0} / \mathrm{H}$ according to Eq. (8). The value of $\mathrm{B}_{0}$ was determined as $0.24 \mathrm{~L} \mathrm{H}_{2, \mathrm{sTP}} / \mathrm{gCOD}_{\text {loaded }}$ from the slope of the curve.

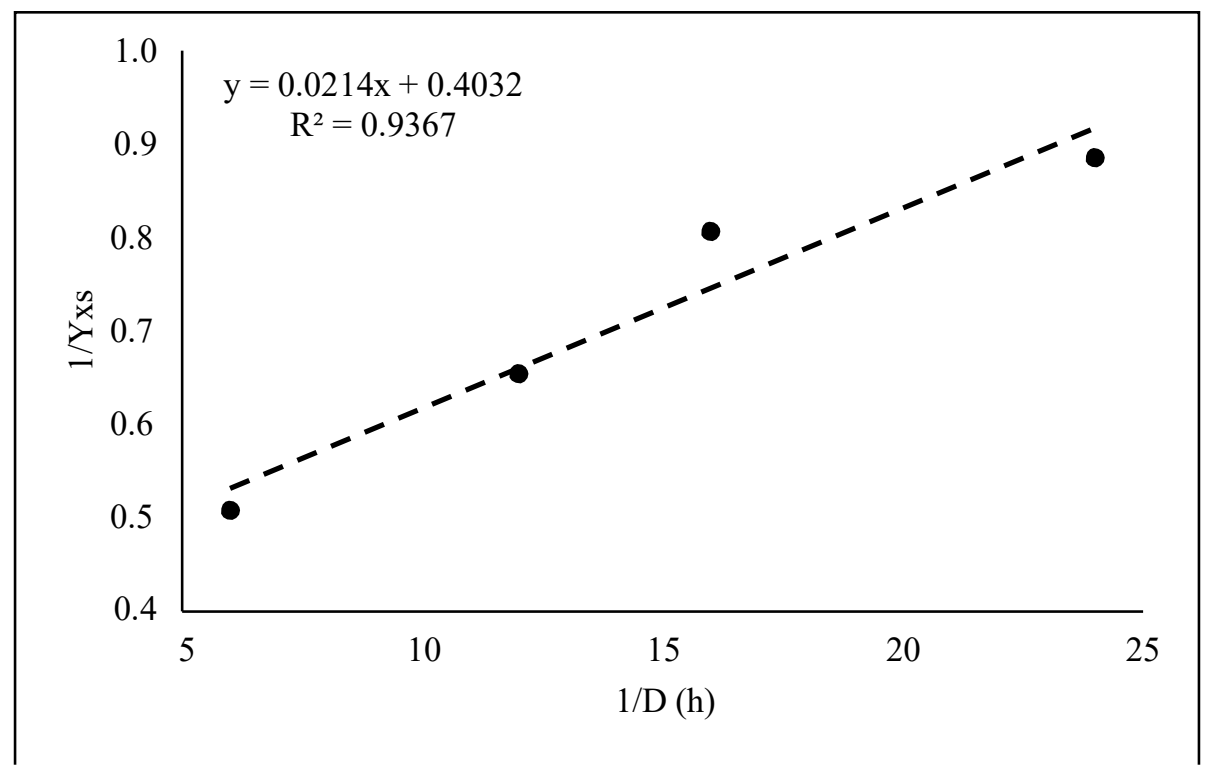

Figure 1 - Determination of yield coefficient $(Y)$ and endogenous decay coefficient $\left(k_{d}\right)$

The kinetic parameters using the Grau model were determined from the plot of $\mathrm{S}_{0} / \mathrm{S}$ versus $1 /\left(\mu+\mathrm{k}_{\mathrm{d}}\right)$. From Figure 2 , the slope is equal to $1 / \mu_{\mathrm{m}}$. Thus, the maximum specific growth rate, $\mu_{\mathrm{m}}$ is $0.371 \mathrm{~h}^{-1}$. The maximum specific growth rate calculated in this study is larger compared to the value found by Mohammadi et al. [21]. They found that the $\mu_{\mathrm{m}}$ is equal to $0.013 \mathrm{~h}^{-1}\left(0.313 \mathrm{day}^{-1}\right)$. This could be due to the difference in temperature where the data used in this paper is from the thermophilic system $\left(55^{\circ} \mathrm{C}\right)$ while Mohammadi et al. used data from the mesophilic system $\left(38^{\circ} \mathrm{C}\right)$.

Figure 3 and Figure 4 show the simulated profile of the volumetric hydrogen production rate for the Grau model alone and compared with other models, respectively. Base on the model, it was estimated that the highest hydrogen production rate could be achieved at HRT around 6-8 hours. However, operation at this HRT is not achievable due to the limitation of the ASBR system. Lin et al. [38] found that the ASBR reactor failed to produce gas at HRT of 4 hours due to the fact that at shorter HRT, the washout of biomass occurs. Lower hydrogen production at a shorter HRT (6 hours) could result from a shift in the metabolic pathway [39, 40]. On the contrary, Kumar et al. [41] found that 2 days (24 hours) HRT gives the best performance of ASBR for digestion of de-oiled jatropha waste with minimum HRT being 1.5 days (36 hours) where the hydrogen production drop. Badiei et al. [42], found that the highest hydrogen production rate was achieved at HRT 72 hours using diluted POME as a substrate in an ASBR system with minimum HRT of 36 hours. They found that the highest production at HRT 72 hours compared to HRT 36 hours probably due to the existence of appropriate condition to activate spore formed bacteria and recover hydrogen-producing bacterial population while at HRT 36 hours, severe washout of sludge occurs in the effluent discharge, dropping the hydrogen production to zero. 


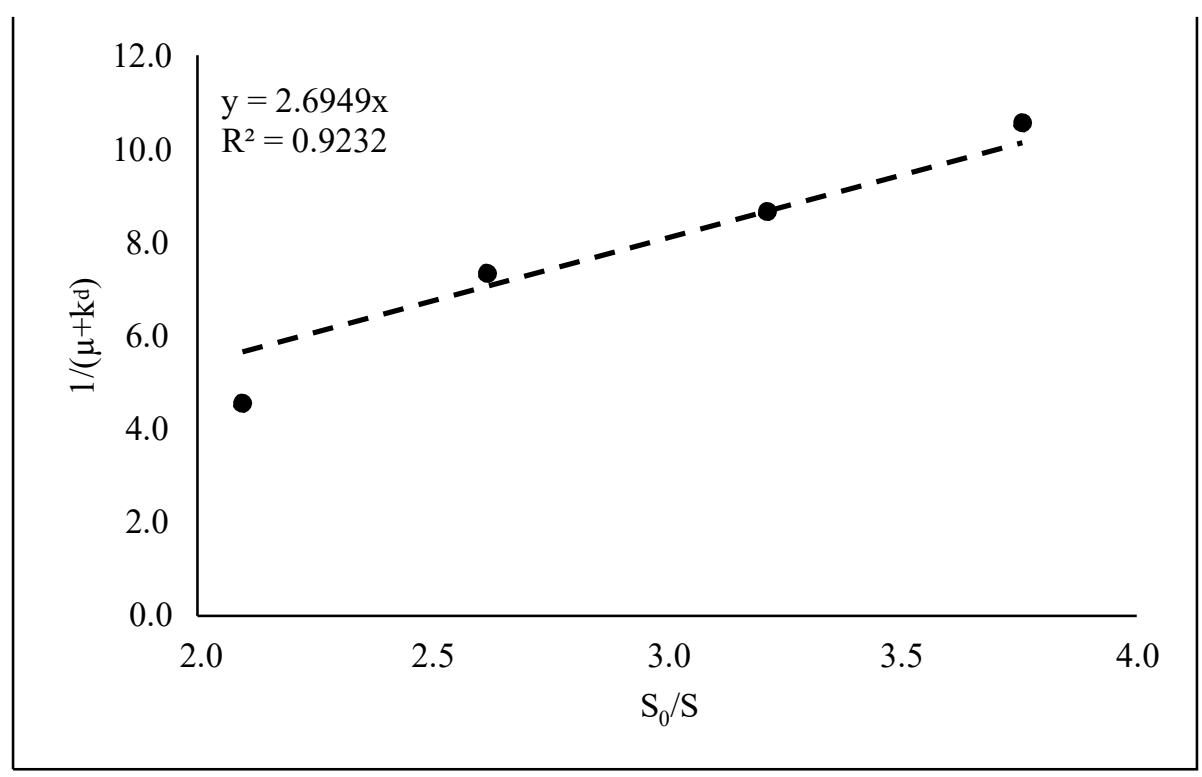

Figure 2 - Determination of $\mu_{\mathrm{m}}$ for Grau model

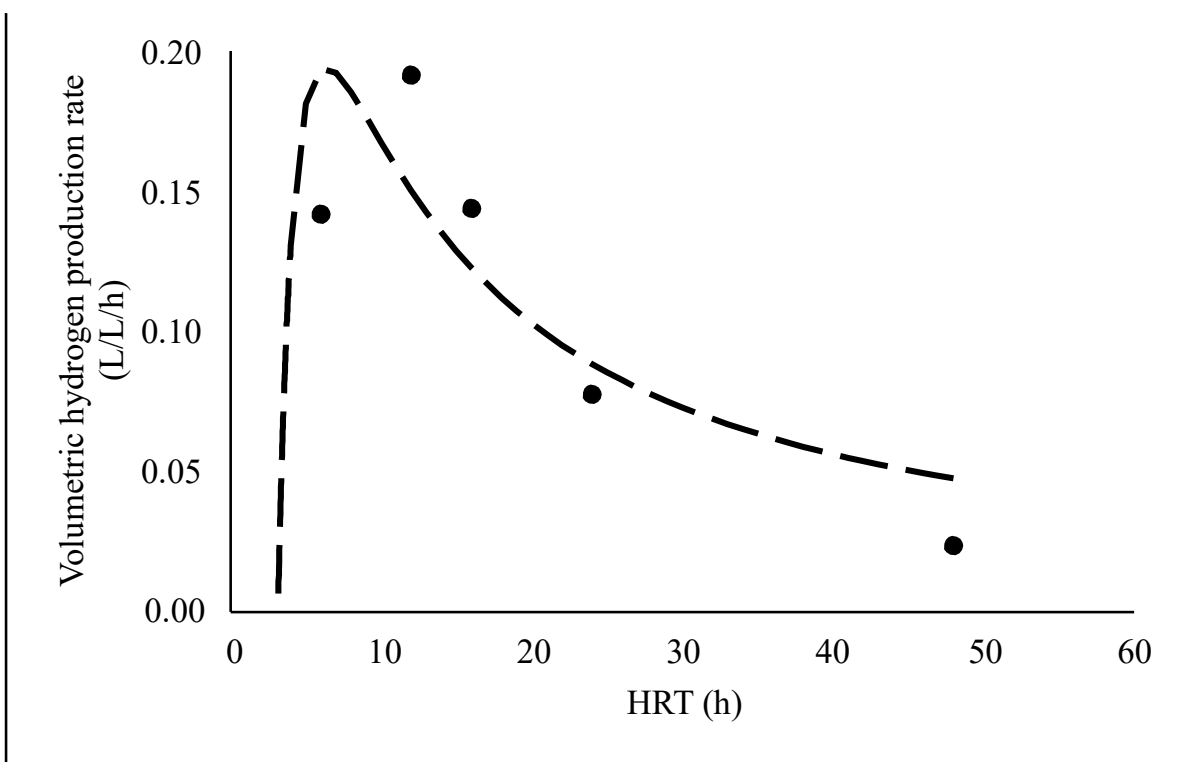

\section{Figure 3 - Change of volumetric hydrogen production rate against HRT ( ) hydrogen production rate (-) simulated profile of the Grau model.}

The biodegradable treatment efficiency $(\mathrm{E})$ of the treatment system, which is defined as the percent of biodegradable substrate utilization of the influent stream through the treatment can be expressed in terms of kinetic parameters (in a dimensionless form) [43]. Figure 5 shows the effluent substrate concentration (S) and the total substrate utilization predicted by using the Grau model. The model can successfully predict the effluent sugar concentration with $\mathrm{R}^{2}$ of 0.97 . However, the model developed in this study failed to predict the parameters for 48 days HRT. This is because, in the long-term operation, ASBR operation was not stable due to the inconsistent $\mathrm{pH}$ in the fermentation media. Furthermore, the accumulation of acetic acid and butyric acid in the fermentation media may also inhibit the production of hydrogen [44]. Bediei et al. [45] also found that in their study, HRT strongly affects the bacterial community, and the primary metabolite of hydrogen fermentation was butyrate. Thus, the microbial community in the reactor could be considered as a function of the productivity of hydrogen.

Table 6 shows the kinetic parameters obtained for influent total carbohydrate concentration of $20 \mathrm{~g} / \mathrm{L}$ used in this study as compared to those reported by other studies. Compared to the mesophilic system[21, 46], this study shows a higher endogenous day rate and a higher maximum specific growth rate. This shows that the thermophilic system has higher losses in cell mass and can operate at much lower HRT compared to the mesophilic system. This study, however, shows a lower maximum specific growth rate compared to the mesophilic dynamic membrane biofilm reactor (DMBR). 
The higher value would result from different populations of microbial in the DMBR system that can operate at much lower HRT.

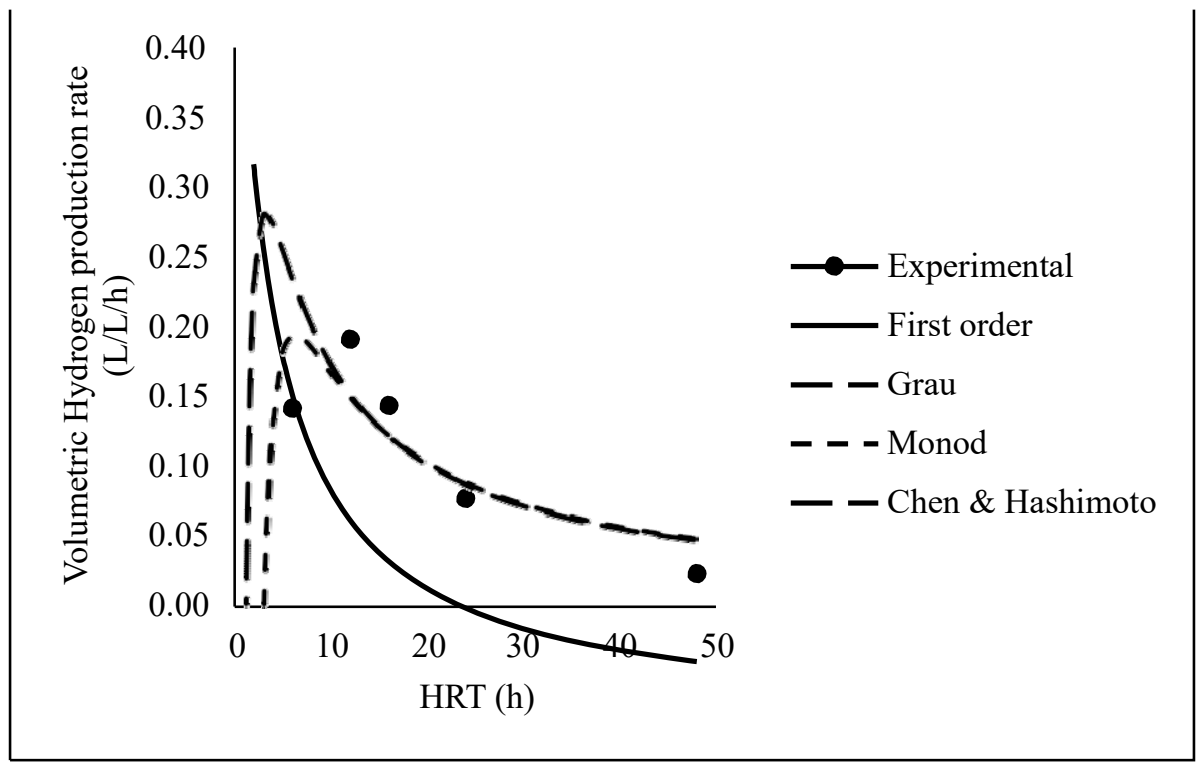

Figure 4 - Comparison of the First-order, Monod, Grau and Chen \& Hashimoto kinetic model

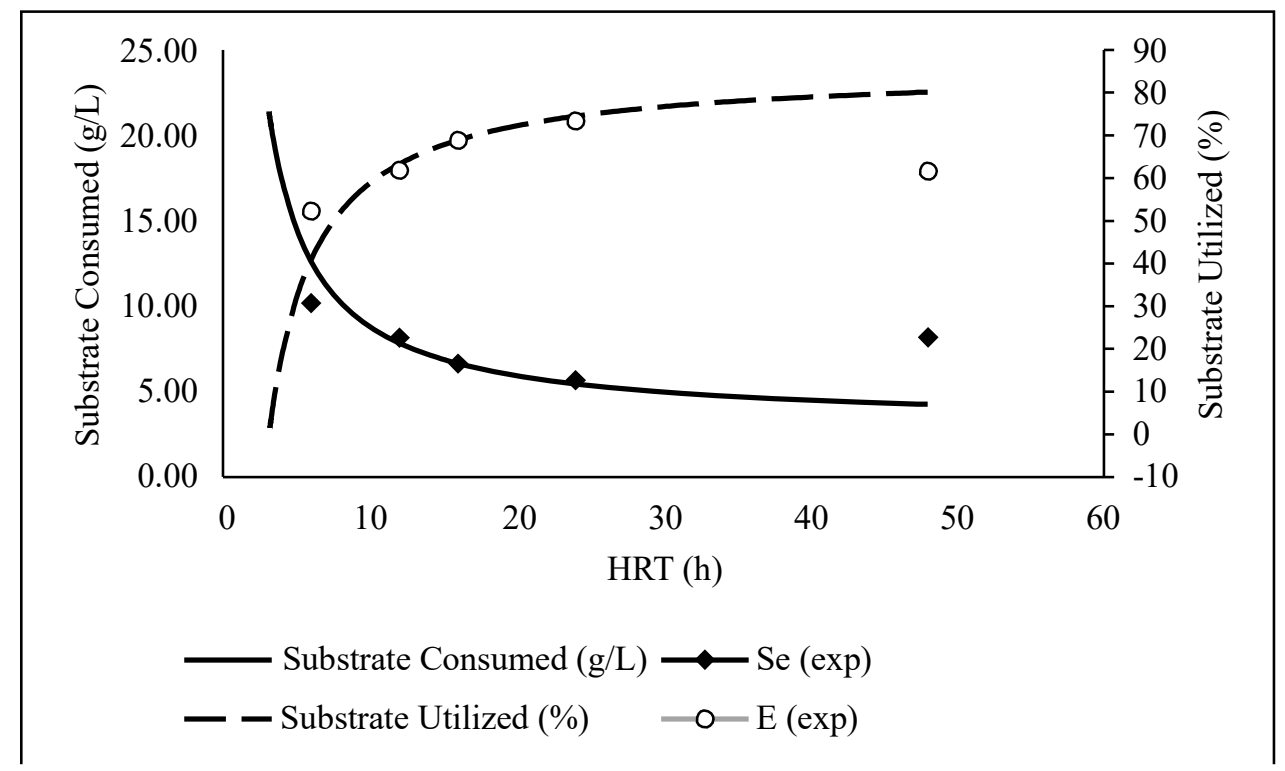

Figure 5 - Changes of effluent substrate concentration and total sugar utilization using Grau model, $(\diamond)$ substrate consumed data, $(O)$ substrate utilized data, and (-) predicted profile.

Table 6: Kinetic parameters comparison for biohydrogen production from POME AD

\begin{tabular}{|c|c|c|c|c|c|c|c|c|c|}
\hline $\begin{array}{c}\text { React } \\
\text { or }\end{array}$ & $\begin{array}{l}\text { Sludg } \\
\text { مـ }\end{array}$ & $\begin{array}{l}\text { Substrat } \\
\text { e }\end{array}$ & $\begin{array}{l}S_{0} \\
(\alpha / L)\end{array}$ & $\begin{array}{l}Y \\
(\alpha / \alpha)\end{array}$ & $\begin{array}{l}\mathrm{k}_{\mathrm{d}}\left(\mathrm{d}^{-}\right. \\
1_{\nu}\end{array}$ & $\begin{array}{c}\mathrm{Ks} \\
(\mathrm{g} / \mathrm{L}) \\
\end{array}$ & $\mu_{\mathrm{m}}\left(\mathrm{h}^{-1}\right)$ & $\begin{array}{c}\text { Coeffici } \\
\text { ent }\end{array}$ & $\begin{array}{l}\text { Referenc } \\
\text { e }\end{array}$ \\
\hline ASBR & Mixe & POME & 2 & 2 & 0.053 & - & 0.371 & COD & This \\
\hline $\begin{array}{l}\text { UAS } \\
\text { B- }\end{array}$ & $\begin{array}{l}\text { Mixe } \\
d\end{array}$ & POME & $\begin{array}{l}1 \\
5\end{array}$ & 0 & $\begin{array}{l}0.004 \\
2\end{array}$ & 9.040 & 0.013 & COD & [17] \\
\hline CSTR & Mixe & Sucrose & 2 & 0 & - & 0.068 & 0.172 & COD & [46] \\
\hline DMB & Mixe & Glucos & 1 & - & - & 1.020 & 0.622 & COD & [47] \\
\hline
\end{tabular}





\section{Conclusion}

The computations of kinetic parameters for first-order, Monod, Grau, and Chen \& Hashimoto model were performed using the substrate concentration, volatile suspended solids, and volumetric hydrogen production rate of actual laboratory-scale ASBR reactor operated at steady-state. Among the tested model, the Grau model simulates the experimental data well with the lowest SSE, RMSE, RSE, MAE, and RAE compare to other models. Even though the Monod model gives a close estimation to the Grau model, the kinetic parameter calculated was not realistic (negative value). Grau model shows that the composition of POME has a substantial impact on the kinetics parameters of the AD process. The computed kinetic parameters of the Grau model are useful for hydrogen generation model validation. This model can be used for the optimization and prediction of volumetric hydrogen production rate as well as substrate utilization in the final effluent of POME anaerobic digestion.

\section{Acknowledgment}

The authors wish to acknowledge Sime Darby Research Sdn. Bhd. for the financial support through grant number KK-2015-002. The first author would like to thank Yayasan Sime Darby (YSD) for the scholarship. We would also like to express our gratitude to UKM-YSD Chair for Sustainable Development: Zero Waste Technology and Taiwan Experience Education Program (TEEP) for their valuable support.

\section{References}

[1] Academy of Sciences Malaysia, A. (2017). The Blueprint for Fuel Cells Industries in Malaysia. Academy of Sciences Malaysia Retrieved from http://www.youblisher.com/p/1726636-FC/.

[2] Ahmad, Z., Ujang, Z., Olsson, G., Latiff, A., \& Aziz, A. (2011). Evaluation of hybrid membrane bioreactor (MBR) for palm oil mill effluent (POME) treatment. International Journal of Integrated Engineering, 1(2), 17-25.

[3] Alqahtani, R. T. (2013). Modelling of biological wastewater treatment.

[4] Argun, H., Kargi, F., Kapdan, I. K., \& Oztekin, R. (2008). Biohydrogen production by dark fermentation of wheat powder solution: Effects of $\mathrm{C} / \mathrm{N}$ and $\mathrm{C} / \mathrm{P}$ ratio on hydrogen yield and formation rate. International Journal of Hydrogen Energy, 33(7), 1813-1819. doi:https://doi.org/10.1016/j.ijhydene.2008.01.038

[5] Arreola-Vargas, J., Flores-Larios, A., González-Álvarez, V., Corona-González, R. I., \& Méndez-Acosta, H. O. (2016). Single and two-stage anaerobic digestion for hydrogen and methane production from acid and enzymatic hydrolysates of Agave tequilana bagasse. International Journal of Hydrogen Energy, 41(2), 897-904.

[6] Aslanzadeh, S., Rajendran, K., \& Taherzadeh, M. J. (2014). A comparative study between single-and two-stage anaerobic digestion processes: Effects of organic loading rate and hydraulic retention time. International Biodeterioration \& Biodegradation, 95, 181-188.

[7] Badiei, M., Jahim, J. M., Anuar, N., \& Abdullah, S. R. S. (2011). Effect of hydraulic retention time on biohydrogen production from palm oil mill effluent in anaerobic sequencing batch reactor. International Journal of Hydrogen Energy, 36(10), 5912-5919.

[8] Badiei, M., Jahim, J. M., Anuar, N., Sheikh Abdullah, S. R., Su, L. S., \& Kamaruzzaman, M. A. (2012). Microbial community analysis of mixed anaerobic microflora in suspended sludge of ASBR producing hydrogen from palm oil mill effluent. International Journal of Hydrogen Energy, 37(4), 3169-3176. doi:https://doi.org/10.1016/j.ijhydene.2011.11.063

[9] Banik, G., Viraraghavan, T., \& Dague, R. (1998). Low temperature effects on anaerobic microbial kinetic parameters. Environmental technology, 19(5), 503-512.

[10] Benefield, L. D., \& Randall, C. W. (1981). Biological process design for wastewater treatment Prentice Hall Series in Environmental Sciences: prentice hall.

[11] Chen, C., Lin, C., \& Chang, J. (2001). Kinetics of hydrogen production with continuous anaerobic cultures utilizing sucrose as the limiting substrate. Applied Microbiology and Biotechnology, 57(1-2), 56-64.

[12] Chen, Y.-R., \& Hashimoto, A. G. (1978). Kinetics of methane fermentation. Paper presented at the Biotechnol. Bioeng. Symp.

[13] Chin, M. J., Poh, P. E., Tey, B. T., Chan, E. S., \& Chin, K. L. (2013). Biogas from palm oil mill effluent (POME): Opportunities and challenges from Malaysia's perspective. Renewable and Sustainable Energy Reviews, 26, 717 726. doi:https://doi.org/10.1016/j.rser.2013.06.008

[14] Dabrock, B., Bahl, H., \& Gottschalk, G. (1992). Parameters affecting solvent production by Clostridium pasteurianum. Appl. Environ. Microbiol., 58(4), 1233-1239.

[15] De Gioannis, G., Muntoni, A., Polettini, A., Pomi, R., \& Spiga, D. (2017). Energy recovery from one-and twostage anaerobic digestion of food waste. Waste management, 68, 595-602.

[16] Dinopoulou, G., Sterritt, R. M., \& Lester, J. N. (1988). Anaerobic acidogenesis of a complex wastewater: II. Kinetics of growth, inhibition, and product formation. Biotechnology and bioengineering, 31(9), 969-978.

[17] Eddy, M. (1991). Wastewater engineering: treatment, disposal and reuse. McGraw-Hill, New York, USA. 
[18] Fdez-Güelfo, L., Álvarez-Gallego, C., Sales, D., \& García, L. R. (2012). Dry-thermophilic anaerobic digestion of organic fraction of municipal solid waste: methane production modeling. Waste management, 32(3), 382-388.

[19] Gavala, H. N., Angelidaki, I., \& Ahring, B. K. (2003). Kinetics and modeling of anaerobic digestion process Biomethanation I (pp. 57-93): Springer.

[20] Grau, P., Dohanyos, M., \& Chudoba, J. (1975). Kinetics of multicomponent substrate removal by activated sludge. Water Research, 9(7), 637-642.

[21] Habeeb, S. A., Latiff, A. A. A., Daud, Z., \& Ahmad, Z. (2014). Sludge Bed Granules' Growth in the HUASB Reactor Treating High Strength Industrial Wastewater. International Journal of Integrated Engineering, 6(1).

[22] Hassan, A., \& Nelson, B. (2012). Invited review: anaerobic fermentation of dairy food wastewater. Journal of dairy science, 95(11), 6188-6203.

[23] Haydar, S., Aziz, J., \& Ahmad, M. (2016). Biological treatment of tannery wastewater using activated sludge process. Pakistan Journal of Engineering and Applied Sciences.

[24] Ibrahim, S. S., Latiff, A. A. A., \& Daud, Z. (2013). Preliminary study: treatment of food industrial wastewater using two-phase anaerobic treatments. International Journal of Integrated Engineering, 5(1).

[25] Kondusamy, D., \& Kalamdhad, A. S. (2014). Pre-treatment and anaerobic digestion of food waste for high rate methane production - A review. Journal of Environmental Chemical Engineering, 2(3), 1821-1830. doi:https://doi.org/10.1016/j.jece.2014.07.024

[26] Kumar, G., \& Lin, C.-Y. (2014). Biogenic hydrogen conversion of de-oiled jatropha waste via anaerobic sequencing batch reactor operation: process performance, microbial insights, and reduction efficiency. The Scientific World Journal, 2014.

[27] Lin, C., \& Chou, C. (2004). Anaerobic Hydrogen Production from Sucrose Using an Acid-Enriched Sewage Sludge Microflora. Engineering in life sciences, 4(1), 66-70.

[28] Lutpi, N. A., Jahim, J. M., Mumtaz, T., Harun, S., \& Abdul, P. M. (2016). Batch and continuous thermophilic hydrogen fermentation of sucrose using anaerobic sludge from palm oil mill effluent via immobilisation technique. Process Biochemistry, 51(2), 297-307.

[29] Ma, J., Yu, L., Frear, C., Zhao, Q., Li, X., \& Chen, S. (2013). Kinetics of psychrophilic anaerobic sequencing batch reactor treating flushed dairy manure. Bioresource technology, 131, 6-12.

[30] Maaroff, R. M., Jahim, J. M., Azahar, A. M., Abdul, P. M., Masdar, M. S., Nordin, D., \& Nasir, M. A. A. (2018). Biohydrogen production from palm oil mill effluent (POME) by two stage anaerobic sequencing batch reactor (ASBR) system for better utilization of carbon sources in POME. International Journal of Hydrogen Energy.

[31] Malaysian Palm Oil Board. (2016). http://bepi.mpob.gov.my/index.php/en/statistics/production/168-production-2016/746-production-of-crude-oilpalm-2016.html

[32] Mata-Alvarez, J., Llabrés, P., Cecchi, F., \& Pavan, P. (1992). Anaerobic digestion of the Barcelona central food market organic wastes: experimental study. Bioresource technology, 39(1), 39-48.

[33] Mohammadi, P., Ibrahim, S., Annuar, M., \& Suffian, M. (2017). Kinetic study of biohydrogen production by anaerobic fermentation in a modified UASB-FF reactor. Journal of Applied Research in Water and Wastewater, 4(2), 370-372.

[34] Monod, J. (1949). The growth of bacterial cultures. Annual Reviews in Microbiology, 3(1), 371-394.

[35] Nagao, N., Tajima, N., Kawai, M., Niwa, C., Kurosawa, N., Matsuyama, T., . . . Toda, T. (2012). Maximum organic loading rate for the single-stage wet anaerobic digestion of food waste. Bioresource technology, 118, 210218. doi:https://doi.org/10.1016/j.biortech.2012.05.045

[36] Oh, T. H., Pang, S. Y., \& Chua, S. C. (2010). Energy policy and alternative energy in Malaysia: issues and challenges for sustainable growth. Renewable and Sustainable Energy Reviews, 14(4), 1241-1252.

[37] Oyelaran, O. A. (2018). Bioconversion of mixed fruit waste as a potential source of biogas and organic fertilizer. International Journal of Integrated Engineering, 10(8).

[38] Park, J.-H., Sim, Y.-B., Kumar, G., Anburajan, P., Park, J.-H., Park, H.-D., \& Kim, S.-H. (2018). Kinetic modeling and microbial community analysis for high-rate biohydrogen production using a dynamic membrane. Bioresource technology, 262, 59-64. doi:https://doi.org/10.1016/j.biortech.2018.04.070

[39] Rahman, S. N. A., Masdar, M. S., Rosli, M. I., Majlan, E. H., Husaini, T., Kamarudin, S. K., \& Daud, W. R. W. (2016). Overview biohydrogen technologies and application in fuel cell technology. Renewable and Sustainable Energy Reviews, 66, 137-162. doi:https://doi.org/10.1016/j.rser.2016.07.047

[40] Ramadhani, L., Damayanti, S., Sudibyo, H., \& Budhijanto, W. (2018). Kinetics of Anaerobic Digestion of Palm Oil Mill Effluent (POME) in Double-Stage Batch Bioreactor with Recirculation and Fluidization of Microbial Immobilization Media. Paper presented at the IOP Conference Series: Materials Science and Engineering.

[41] Rasdi, Z., Mumtaz, T., \& Hassan, M. A. (2012). Kinetic analysis of biohydrogen production from anaerobically treated POME in bioreactor under optimized condition. International Journal of Hydrogen Energy, 37(23), 1772417730.

[42] Sales, F., Pereira, J., \& Abreu, C. (2000). Estudo Hidrodinâmico de um Reator de Leito de Lama Trifásico. Paper presented at the XXVIII Congresso Brasileiro de Sistemas Particulados, Teresópolis, Brazil. 
[43] Seengenyoung, J., Sompong, O., \& Prasertsan, P. (2014). Comparison of ASBR and CSTR reactor for hydrogen production from palm oil mill effluent under thermophilic condition. Advances in Bioscience and Biotechnology, 5(03), 177.

[44] Van Andel, J., Zoutberg, G., Crabbendam, P., \& Breure, A. (1985). Glucose fermentation byClostridium butyricum grown under a self generated gas atmosphere in chemostat culture. Applied Microbiology and Biotechnology, 23(1), 21-26.

[45] Wang, J., \& Wan, W. (2009). Kinetic models for fermentative hydrogen production: A review. International Journal of Hydrogen Energy, 34(8), 3313-3323. doi:https://doi.org/10.1016/j.ijhydene.2009.02.031

[46] Wu, T. Y., Mohammad, A. W., Jahim, J. M., \& Anuar, N. (2009). A holistic approach to managing palm oil mill effluent (POME): Biotechnological advances in the sustainable reuse of POME. Biotechnology Advances, 27(1), 40-52. doi:https://doi.org/10.1016/j.biotechadv.2008.08.005

[47] Wu, T. Y., Mohammad, A. W., Jahim, J. M., \& Anuar, N. (2010). Pollution control technologies for the treatment of palm oil mill effluent (POME) through end-of-pipe processes. Journal of Environmental Management, 91(7), 1467-1490. doi:https://doi.org/10.1016/j.jenvman.2010.02.008 